\title{
PRACTICAL TUBE NESTS FOR TRANSPORTATION AND MAILING OF LIVE ANT COLONIES
}

\section{A. BUSCHINGER and J. HEINZE}

Institut für Zoologie, Fachbereich Biologie, Technische

Hochschule Darmstadt, Schnittspahnstr. 3, D-6100 Darmstadt, FRG

Reçu le $1^{\text {er }}$ février 1988

Accepté le 27 mars 1988

\section{SUMMARY}

A cheap, light and stable system for temporary housing and mailing live ant colonies, or other small insects, is described ( $f$ ig. 1 ). Only two sizes of transparent and flexible PVC-tube, PVC-stoppers and a piece of copper gauze are needed to make the system. The insects are aspirated into the tubes.

\section{RESUME}

Un système pratique pour transporter et expédier des colonies de fourmis vivantes

On décrit un système économique, léger et stable pour héberger temporairement et pour expédier des colonies de fourmis vivantes, ou d'autres petits insectes (fig. I). Seulement deux types de tubes transparents et flexibles de PVC, des bouchons de PVC et un morceau de gaze de cuivre sont nécessaires pour faire le système. Les insectes sont aspirés dans les tubes.

Myrmecologists are often confronted with the problem of carrying live samples or complete colonies of ants with them for several days or weeks, during field work, or to mail such material. Difficulties arise when travelling by plane, were weight and volume of baggage are restricted, when high numbers of heavy or large containers with live insects have to be carried. Small glass tubes may break, or they are too tightly closed so that the insects asphyxiate after some hours or days.

We have developed a system of transparent, flexible PVC-tubes which proved very effective and practical, and which is suited to overcome most of the problems mentioned. 

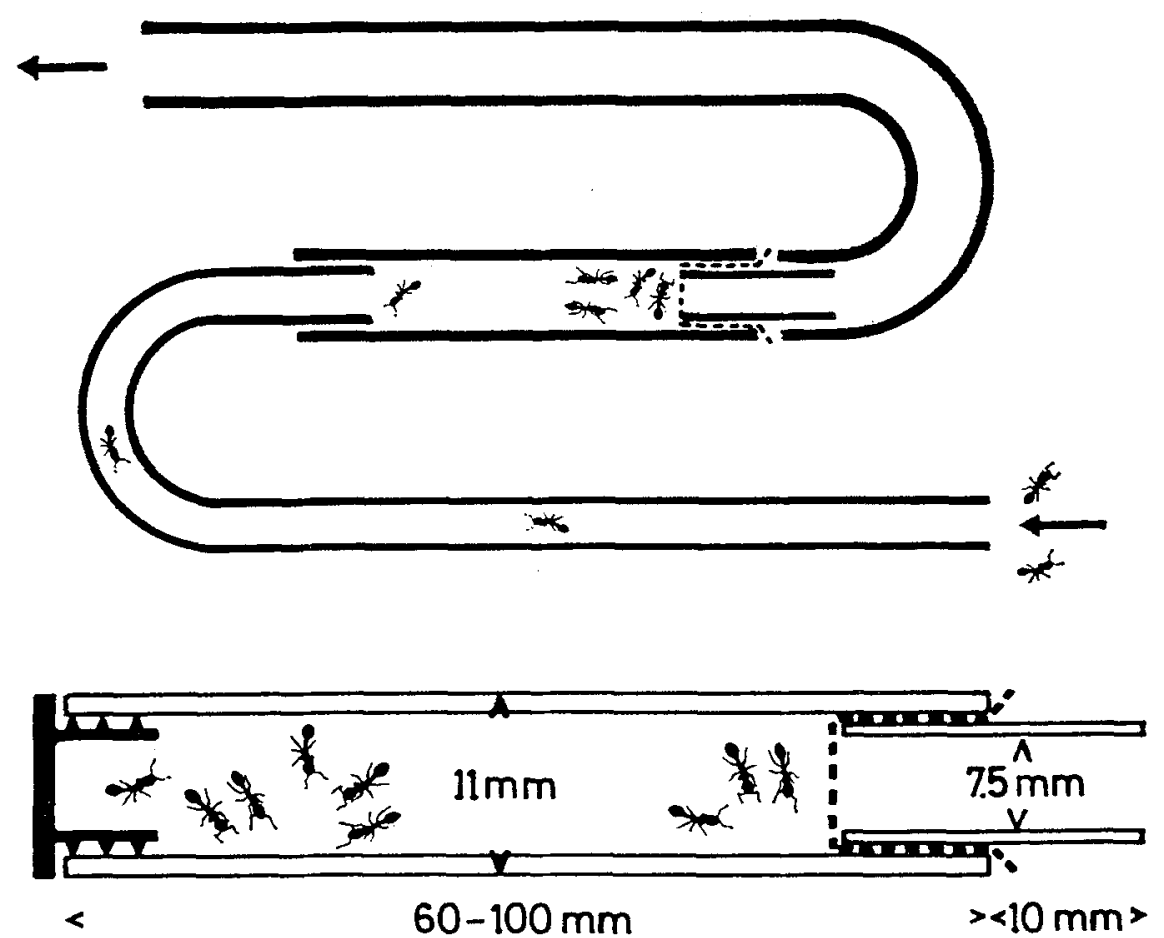

Fig. 1. - PVC-tube system for transportation and mailing live ant colonies.

Below: "Container" with stopper (left end) and small tube with copper gauze inserted into the right end.

Above: Aspirating the ants into the "container" through a piece of the smaller tube inserted into the "stopper end", and a piece of the wider tube slipped over the "gauze-end" of the container.

Fig. 1. - Systėme en tubes de PVC pour transporter et expédier des colonies de fourmis vivantes.

En bas: "Container" avec bouchon (bout gauche) et tube étroit avec gaze de cuivre mis dans le bout droit.

En haut: Les fourmis sont aspirées dans le container par une pièce du tube étroit mis dans les "bout à bouchon", et une pièce du tube large poussée sur le "bout à gaze " du container.

Figure 1 shows the complete system. It consists of two sizes of PVCtubes the smaller of which fits tightly into the wider one. A piece of the wide tube ("container") houses the ants (or other small insects). One of its ends is closed with a PVC-stopper, in the other end a short piece of the smaller tube is inserted. Its inner end is covered by a piece of copper gauze, the margin of which is bent over the smaller tube and squeezed between the walls when the smaller tube is inserted into the container (It is helpful first to push the gauze a little into the opening of the wide tube, 
with the aid of a pencil etc., and then to insert the small tube). The copper gauze with a mesh width of 0.2 to $0.5 \mathrm{~mm}$ is commercially available. Gauzes of other resistant materials are equally suited.

Filling the ants into the containers requires only two longer pieces of the two sizes of tubes $(\mathrm{ca} 30-50 \mathrm{~cm})$. The smaller one, after removing the stopper, is inserted into the open end of the container, the wider tube is slipped over the small piece of tube in the "gauze-end ". The ants can now be aspirated into the container (fig. 1). Keeping the container upright and tapping its wall shakes the ants down towards the gauze, the small tube is removed and the stopper is replaced.

In dry conditions a number of these containers may be wrapped into a thick layer of humid paper or tissue (e.g., a towel), which then may be sealed in a plastic bag etc., to prevent desiccation: The paper or tissue contains sufficient hymidity and air for days or even week.

We have used this system mainly for transportation of leptothoracine ants the colonies of which have a volume of usually less than $5 \mathrm{cc}$, including brood and some soil, wood dust, and other material from the nesting sites. The colonies have survived three-weeks-collecting trips in North Africa and in Canada, and the travelling back to Germany. As food some small insect pieces or filter paper soaked with honey were applied about once a week in the "stopper-end" of the container. 